\title{
Dietary analysis of the House Swift (Apus nipalensis) in Hong Kong using prey DNA in faecal samples
}

\author{
Chun Ting Chung ${ }^{1 *} \mathbb{D}$, Hok Sze Wong ${ }^{2}$, Man Long Kwok' ${ }^{1}$ Qi Meng ${ }^{1}$ and King Ming Chan ${ }^{1}$
}

\begin{abstract}
Background: To understand the dietary composition of the highly aerial swift (Apodidae), ecologists conventionally depend on the morphological identification of prey items from food boluses or stomach contents, but these techniques are often invasive, require expertise in identification, and often cannot produce accurate identifications at the species level.

Methods: DNA barcoding was used to analyse the dietary composition of House Swifts (Apus nipalensis) in Hong Kong, China. Faecal samples from five different colonial nest sites were collected between 2019 and 2020. We used universal primers to amplify a region of the cytochrome $C$ oxidase gene from prey DNA in the faecal samples for identification purposes.

Results: Ten different orders and 44 families from three different classes of Arthropoda were identified in the collected faecal samples. Hymenoptera, Hemiptera and Diptera were the most prevalent groups of prey found in the samples. Differences in the dietary composition of House Swifts during the breeding (April to September) and nonbreeding (October to March) season were also found. Hymenoptera, particularly ants (Formicidae), were predominant in the diet during the breeding season, whereas Diptera and Hemiptera were predominant during the non-breeding season.

Conclusion: The prey groups identified in this study were similar to those identified in a previous study of the diet of House Swift, which also suggests a possible role of House Swifts in reducing the numbers of local insect pests. This study demonstrates the usefulness of applying molecular tools for the dietary analysis of aerial feeders. Conserving local forested areas may be crucial for the maintenance of House Swift population.
\end{abstract}

Keywords: Diet, DNA barcoding, House swift, Urbanisation threat

\section{Background}

House Swifts (Apus nipalensis; Hodgso 1836) are typical swifts in the Apodidae family. They are distributed in Southeast and East Asia, with a westward range reaching as far as Nepal (BirdLife International 2016). Their nests are usually built in close proximity to humans, and

*Correspondence: cct20054@gmail.com

1 School of Life Sciences, The Chinese University of Hong Kong, Sha Tin 999077, N.T, China

Full list of author information is available at the end of the article clusters of nests are often found under the eaves or ceilings of buildings in urban areas. They are gregarious, foraging on diurnal aerial insects in various habitats, from forests to fish ponds (Chantler and Driessens 1995; Carey et al. 2001).

In Hong Kong, a city located on the southeastern coast of China, House Swifts are common year-round residents. They build their nests on buildings in many of the old town areas (Carey et al. 2001). In a survey of House Swift nests in 2019, 3282 nests were recorded across Hong Kong, and approximately two thirds of these nests

(c) The Author(s) 2021. This article is licensed under a Creative Commons Attribution 4.0 International License, which permits use, sharing, adaptation, distribution and reproduction in any medium or format, as long as you give appropriate credit to the original author(s) and the source, provide a link to the Creative Commons licence, and indicate if changes were made. The images or other third party material in this article are included in the article's Creative Commons licence, unless indicated otherwise in a credit line to the material. If material is not included in the article's Creative Commons licence and your intended use is not permitted by statutory regulation or exceeds the permitted use, you will need to obtain permission directly from the copyright holder. To view a copy of this licence, visit http://creativeco mmons.org/licenses/by/4.0/. The Creative Commons Public Domain Dedication waiver (http://creativecommons.org/publicdomain/ zero/1.0/) applies to the data made available in this article, unless otherwise stated in a credit line to the data. 
were observed to be active (The Hong Kong Bird Watching Society, 2020, unpublished data). Over $90 \%$ of the nests and all active nests were found in the New Territories, with the greatest number of active nests found in Sha Tin, followed by the North and Yuen Long Districts. Approximately 1200 adult House Swifts were found around Hong Kong during this survey.

Swifts are highly adapted to aerial living, and their food sources are mainly organisms that are small enough to use uplifting currents and wind for dispersion or even migration, which includes winged insects and aerial plankton (Gatehouse 1997; Cusimano et al. 2016). Conventional analyses of swifts' diets mostly have been based on the visual identification of ingested prey items in food boluses delivered to nestlings (Lack and Owen 1955; Hails and Amirrudin 1981; Tarburton 1986; Marín 1999; Lourie and Tompkins 2000; Collins et al. 2010; Garciadel-Rey et al. 2010), in the stomach (Hespenheide 1975; Kow 1980; Cheng and Zhou 1987; Kopij 2000; Nguyên Quang et al. 2006; Collins and Hespenheide 2016), or in faeces (Waugh 1978; Cucco et al. 1993).

Two previous studies have investigated the diet of the House Swifts by stomach contents. Kow (1980) collected House Swifts weekly from 1963 to 1964 in Yunnan, China and investigated the stomach contents of 124 collected swifts. Coleoptera, Diptera, Hymenoptera, Hemiptera and Homoptera were the five major prey orders found in the stomach of House Swifts. In which Coleoptera was found to be the greatest in both number of prey items and frequency of occurrence. He also found Diptera, Hemiptera and Hymenoptera were dominant in the first half of a year (February to June), while Coleoptera and Hemiptera dominated the diets in the second half (July to December).

Another study was conducted by Nguyên Quang et al. (2006) in Vietnam, they collected and analysed the stomach contents of 120 House Swifts during breeding seasons in 1994 and 1995. Coleoptera, Hemiptera and Hymenoptera were also found to be the major prey items for House Swifts during breeding seasons. However, the frequency of occurrence of the Coleoptera in was lower than that of Hymenoptera and Hemiptera.

The procedure used to analyse prey items in the stomachs of swifts requires killing the birds and thus, it is considered to be unethical and not suitable for continuous monitoring. Analysing food boluses is seemingly a better method, because it is non-lethal, it is suitable for continuous monitoring, and undigested prey items can be used for morphological identification. Nevertheless, this method is invasive to some extent, as trapping and handling of the birds is required. In addition, the time frame for food bolus collection is restricted to the breeding season and crushing the prey with the beak or prolonged storage in alcohol can hinder the visual identification of prey items (Lack and Owen 1955; Collins et al. 2010).

Dietary analysis based on faecal samples is the only non-invasive method, besides observation, that allows the continuous monitoring of diets. However, completely digested prey is difficult to identify morphologically, and few scholars have used this method for analysing swift diets. During the past two decades, DNA barcoding techniques for species identification have received much attention and have facilitated dietary analysis using faecal samples.

The fundamental principle behind dietary analysis using DNA barcoding is based on the fact that DNA in faeces contains barcode regions originating from different prey items. Prey DNA remains in the gut contents and the faeces, and can be amplified for species identification. The major advantages of using DNA barcoding for identification, compared with conventional morphological identification methods, include the lack of a requirement for prior knowledge to identify prey and the ability to identify prey at the species level (Valentini et al. 2009; Sousa et al. 2019). Thus, species identification by DNA barcoding using faecal samples is a non-invasive method for the continuous monitoring of a species' diet.

Despite the usefulness of DNA barcoding for precise dietary analysis and its use for analysing the diets of various bird species, including albatrosses (McInnes et al. 2017), penguins (Deagle et al. 2007), and sandpipers (Gerwing et al. 2016), the technique had not been used for the dietary analysis of swifts until a recent study of swiftlets (Aerodramus sp.) in Malaysia, which used DNA extracted from faecal samples (Chan et al. 2019).

In this study, the dietary composition of House Swifts in Hong Kong was analysed by DNA barcoding using faecal samples. Although Hong Kong is highly urbanised and is one of the most densely populated cities in the world, House Swifts sustain a relatively stable population in the city. This study aimed to determine the resource usage of Hong Kong's House Swifts, to provide basic information on the local urban ecology. Dietary analysis was performed on faecal samples, as this allows noninvasive, continuous monitoring of an individual or a colony. It was thus possible to investigate temporal variations in the dietary composition of House Swifts colonies in this study. Multiple pre-identified colonial nest sites located in different parts of Hong Kong were included to examine spatial variation between different colonies. The results of this study were compared with the results of two previous studies of the House Swift diet, based on stomach contents, conducted in Yunnan, China (Kow 1980) and Vietnam (Nguyên Quang et al. 2006). 


\section{Methods}

\section{Site selection}

Five House Swift colonial nest sites, which were previously identified and found to be accessible in a nest count survey conducted by the Swift and Swallow Research Group of the Hong Kong Bird Watching Society, were selected for faecal sample collection. The five nest sites were: (1) the University Library of the Chinese University of Hong Kong (CUHK) in the New Territories, (2) the Mong Kok Government Office Building (MK) in Kowloon, (3) the Pok Fu Lam Fire Station (PFL) in Hong Kong Island, (4) the Mui Wo Fire Station (MW), and (5) the Ngong Ping 360 Airport Island Angle Station at Chek Lap Kok (CLK) on Lantau Island (Fig. 1). Prior permission for the sampling events conducted inside the two fire stations had been granted from the Fire Services Department of the Hong Kong Government.

\section{Sample collection}

All faecal samples were collected from the ground beneath the five nest sites, which were paved with either concrete or stone at all locations. For the CUHK nest site, samples were collected monthly from early May 2019 to late March 2020. For all other nest sites (MK, PFL, MW, CLK), samples were collected in August 2019 and January 2020 (Table 1). The sampling period covered both the breeding (May to September) and non-breeding (October to April) season of the House Swift.

During sampling, the faecal samples were inspected to ensure that no living insects were contaminating them. For the samples collected from the CUHK site, genomic DNA was extracted immediately after sample collection. For the other nest sites, samples were first stored at $-20{ }^{\circ} \mathrm{C}$ before extraction within 3 days of collection, to minimise the deterioration of DNA during prolonged storage.

\section{DNA extraction and PCR amplification}

Genomic DNA was extracted from the faecal samples using a QIAamp PowerFecal Pro DNA Kit (Qiagen, Hilden, Germany), following the manufacturers protocol. The samples $(250 \mathrm{mg}$ in $2 \mathrm{~mL}$ bead column provided in the kit) were homogenized at $4000 \mathrm{rpm}$ for $20 \mathrm{~s}$ in $1 \mathrm{~mL}$ of buffer provided with the kit, using a Minilys homogenizer (Bertins Instruments, Avantor; VWR International, Radnor, PA, USA).

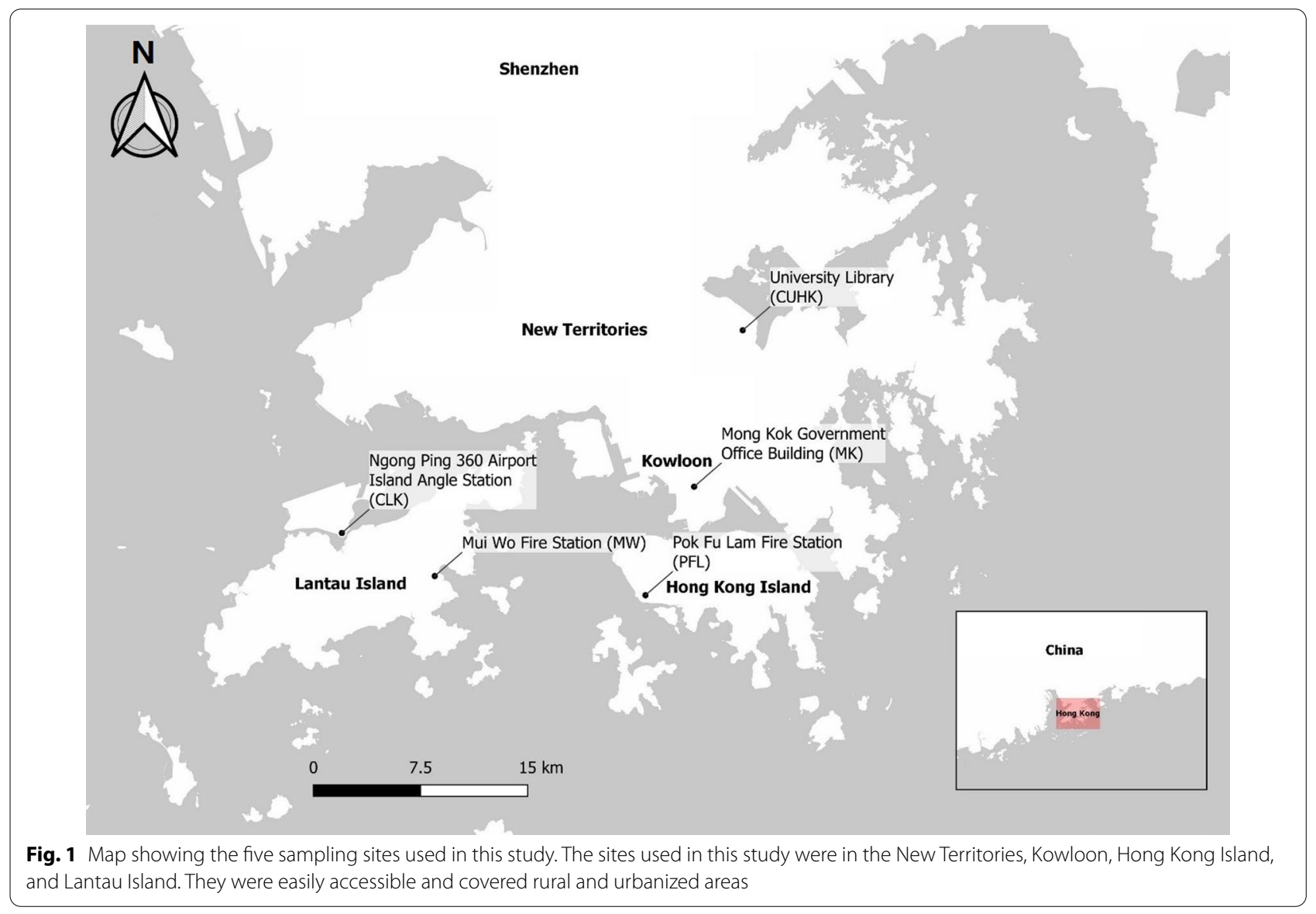


Table 1 Summarisation of the location, date, and number of House Swift faecal samples collected in this study

\begin{tabular}{|c|c|c|c|}
\hline Location & Date & Number of samples & $\begin{array}{l}\text { Number of samples } \\
\text { with successful } \\
\text { amplification }\end{array}$ \\
\hline \multirow[t]{12}{*}{ CUHK } & 1 May 2019 (E. May) & 14 & 10 \\
\hline & 31 May 2019 (L. May) & 20 & 18 \\
\hline & 28 Jun 2019 (Jun) & 20 & 18 \\
\hline & 30 Jul 2019 (Jul) & 12 & 0 \\
\hline & 28 and 29 Aug 2019 (Aug) & 20 & 9 \\
\hline & 25 Sep 2019 (Sep) & 12 & 9 \\
\hline & 28 Oct 2019 (Oct) & 12 & 8 \\
\hline & 28 Nov 2019 (Nov) & 14 & 10 \\
\hline & 25 Dec 2019 (Dec) & 14 & 9 \\
\hline & 24 Jan 2020 (Jan) & 10 & 9 \\
\hline & 26 Feb 2020 (Feb) & 12 & 12 \\
\hline & 25 Mar 2020 (Mar) & 10 & 9 \\
\hline \multirow[t]{2}{*}{ CLK } & 13 Aug 2019 (Aug) & 8 & 9 \\
\hline & 18 Jan 2020 (Jan) & 10 & 2 \\
\hline \multirow[t]{2}{*}{ MK } & 13 Aug 2019 (Aug) & 12 & 12 \\
\hline & 24 Jan 2020 (Jan) & 10 & 8 \\
\hline \multirow[t]{2}{*}{ MW } & 13 Aug 2019 (Aug) & 14 & 8 \\
\hline & 18 Jan 2020 (Jan) & 9 & 8 \\
\hline \multirow[t]{2}{*}{ PFL } & 13 Aug 2019 (Aug) & 10 & 12 \\
\hline & 18 Jan 2020 (Jan) & 4 & 8 \\
\hline Total & & 247 & 188 \\
\hline
\end{tabular}

The primer pairs, MLep F1 (5'-GCTTTCCCACGA ATAAATAATA-3') and Lep R1 (5'-TAAACTTCTGGA TGTCCAAAAAATCA-3'), targeting a 407-bp fragment of the standard 658-bp cytochrome $\mathrm{C}$ oxidase (COI) gene barcoding region, were used to amplify prey DNA from the faecal samples. This pair of primers was originally designed to amplify DNA from degraded museum insect specimens and has been shown to be robust in the recovery of gene fragments, the MLep F1 primer binding site is around 200-bp away from the $5^{\prime}$ end of the COI (Hajibabaei et al. 2006).

However, after a few trials, this pair of universal primers was found to amplify the House Swift COI gene. As the predominance of predator DNA in the faecal samples could hinder the amplification of trace prey DNA, following Vestheim and Jarman (2008), a blocking primer, Anip Blk R1 (5'-CCAAAAAATCAGAATAGGTGTTGATAT ATA-C3 spacer-3') was designed to block the annealing of the reverse primer and thus, the amplification of the House Swift COI gene. Effective suppression of predator gene amplification was demonstrated when the blocking primer was used at 10 times the concentration of the amplification primers.

All PCRs were performed in a reaction mix containing $1 \mu \mathrm{L}$ of the extracted faecal DNA, $10 \mu \mathrm{L}$ of Premix Ex
Taq polymerase (Takara, Kusatsu, Japan), $0.5 \mu \mathrm{M}$ of each primer, and $5 \mu \mathrm{M}$ of blocking primer, and made up to $20 \mu \mathrm{L}$ with Milli-Q water. Duplicate reactions were performed for each sample with a water blank as the negative control.

The thermal cycling protocol of the PCRs consisted of an initial denaturation at $94{ }^{\circ} \mathrm{C}$ for $3 \mathrm{~min}$, followed by five cycles of denaturation at $94{ }^{\circ} \mathrm{C}$ for $30 \mathrm{~s}$, annealing at $45^{\circ} \mathrm{C}$ for $30 \mathrm{~s}$, and elongation at $72{ }^{\circ} \mathrm{C}$ for $1 \mathrm{~min}$; 35 cycles of denaturation at $94{ }^{\circ} \mathrm{C}$ for $30 \mathrm{~s}$, annealing at $51^{\circ} \mathrm{C}$ for $30 \mathrm{~s}$, and elongation at $72{ }^{\circ} \mathrm{C}$ for $1 \mathrm{~min}$; and a final extension at $72{ }^{\circ} \mathrm{C}$ for $5 \mathrm{~min}$. The Takara PCR Thermal Cycler Dice system was used for all amplifications.

PCR products were separated and visualised in 1.5\% agarose gels stained with RedSafe nucleic acid staining solution (iNtRON, Seongnam, South Korea). Bands of the expected size (approximately $400 \mathrm{bp}$ ) were cut using a clean spatula and the PCR products were purified using a MEGAquick-spin Plus Total Fragment DNA Purification Kit (iNtRON).

\section{Clone library construction and sequencing}

Purified PCR products were ligated into pMD-18 T vectors (Takara) with an overnight incubation at $16{ }^{\circ} \mathrm{C}$. The ligation products were then transformed into chemically 
competent E. coli $\mathrm{DH} 5 \alpha$ cells (New England Biolabs, Ipswich, MA, USA) as follows: cells were incubated on ice for $30 \mathrm{~min}$, heat shocked at $42{ }^{\circ} \mathrm{C}$ in a dry bath for $45 \mathrm{~s}$, and then immediately returned on ice for $1 \mathrm{~min}$. After $1 \mathrm{~h}$ of recovery in SOC medium, the cells were spread on LB agar plates containing ampicillin and X-gal and IPTG for blue-white screening. The plates were then incubated at $37{ }^{\circ} \mathrm{C}$ overnight. On average, seven white colonies were picked from each library and further cultured in $0.5 \mathrm{~mL}$ of LB broth with ampicillin at $37^{\circ} \mathrm{C}$ overnight for sequencing. The cultured colonies with faecal DNA inserts were sent to BGI Group (Shenzhen, China) for unidirectional Sanger sequencing using the M13-47 primer (5'-CGCCAGGGTTTTCCCAGTCACGAC-3').

\section{Taxa assignment and data analysis}

Sanger sequencing data were viewed using BioEdit Version 7.2.5 (Hall 1999). Nucleotide sequences within for each sample were aligned using ClustalW and the primer and vector sequences were trimmed using MEGA version X (Kumar et al. 2018). The COI gene sequences were then compared with all barcode records on BOLD, using the built-in identification system (Ratnasingham and Hebert 2007).

Species-level assignments, based on the method described by Clare et al. (2011), were made when query sequences showed greater than $98 \%$ similarity with the reference sequence. Similarity levels lower than this threshold imply the absence of a reference sequence equivalent to the query sequence, and higher taxa assignment based only on genetic distance is prone to falsepositive errors (Ross et al. 2008). As suggested by Wilson et al. (2011), a tree-based identification method was used to mitigate the risk of type I errors for queries with a similarity lower than $98 \%$. Neighbour-joining trees were generated using the BOLD identification system and taxa were assigned if the query sequence was nested within a clade consisting of reference sequences from a single taxon. Further, as GenBank was reported to outperform BOLD in species-level identification on insects (Meiklejohn et al. 2019), all sequences assigned to genus or species-level were crosschecked with BLAST search tool in GenBank.

Two metrics were used to report the dietary composition of the House Swifts in this study. The first metric was the percentage of the clone $(\% \mathrm{C})$ calculated from the proportion of clones consisting of DNA of a given prey group in a sample with normalisation, such that each sample was weighted equally to mitigate the problem of differences in the number of clones with prey sequences in different samples. The second metric was the percent frequency of occurrence (\%FO), which was calculated from the number of times a given prey group was identified in a set of samples divided by the total number of samples in that set. As these metrics both have inherent bias, both are reported in this study for a better overview of the birds' dietary composition.

Furthermore, the \%C and \%FO values for different prey groups in the breeding season (early May to September) and non-breeding season (October to March), and for samples collected in August 2019 and January 2020 from the five sites, were used for multivariate analyses of temporal and spatial effects, respectively. Non-metric multidimensional scaling (NMDS) and analysis of similarity (ANOSIM) were applied in parallel for comparisons using the Bray-Curtis similarity index, with 9999 permutations. Similarity percentages (SIMPERs) were also calculated to determine the contribution of different prey groups to the observed spatial and temporal differences. Taxon accumulation curves were also generated for evaluating the relationship between sampling effort and species discovery. The generation of taxon accumulation curves and all multivariate analyses were performed using PAST version 4.01 (Hammer et al. 2001).

\section{Results \\ Prey identification by DNA barcoding}

Among the 247 samples collected from five different colonial nest sites in Hong Kong between 2019 and 2020, 188 (76\%) sequences could be amplified with the MLep F1/Lep R1 primer pair and prey DNA sequences were identified in 163 samples (66\%). All amplicons were visualised on agarose gels and were excised for TA cloning into pMD18-t and subsequent transformation.

Of the 1344 clones that were picked for sequencing, $418(31 \%)$ were found to contain the predatory COI gene sequence and $79(6 \%)$ were found to contain contaminants like fungal, bacterial, and plant species (Additional file 1: Table S1). On average, 1.6 distinct taxa were detected at the species level in each faecal sample containing prey sequences, and a maximum of six distinct taxa were identified from a single faecal sample.

All prey sequences identified in the faecal samples were from species within the phylum Arthropoda. The species were from three different classes (Arachnida, Collembola, and Insecta), comprising a total of ten orders (Mesostigmata, Trombidiformes, Entomobryidae, Blattodea, Coleoptera, Diptera, Hemiptera, Hymenoptera, Lepidoptera, and Odonata) and 44 families. Of all the sequences assigned to a prey taxon, approximately $58 \%$ could be identified at the genus level and approximately $34 \%$ were identifiable at the species level (Table 2).

Although no asymptotic taxon accumulation curves could be generated at the species, families/infraorders nor order level, higher taxonomic rank accumulation 
Table 2 List of prey items identified in House Swift faecal samples from five different nest sites in Hong Kong between 2019 and 2020

\begin{tabular}{|c|c|c|c|c|c|c|c|}
\hline Class & Order & Family & Genus & Species & Habitats & $\% F O$ & Location (Time) \\
\hline \multirow[t]{3}{*}{ Arachnida } & Mesostigmata & Phytoseiidae & / & / & & 100.00 & CUHK (L. May) \\
\hline & Sarcoptiformes & Proctophyllodidae ${ }^{1}$ & / & / & & & CUHK (Jun); CLK (Aug) \\
\hline & Trombidiformes & / & / & / & & 100.00 & MW (Aug) \\
\hline Collembola & Entomobryomorpha & Entomobryidae & Seira+ & Seira sp.+ & $\mathrm{SL}(?)$ & 100.00 & CUHK (Mar) \\
\hline \multirow[t]{36}{*}{ Insecta } & Blattodea & Termitidae^ & Odontotermes & $\begin{array}{l}\text { Odontotermes formosa- } \\
\text { nus }\end{array}$ & $S L, F, A$ & 100.00 & $\begin{array}{c}\text { CUHK (L. May, Aug, Sep } \\
\text { Nov); CLK (Aug); MK } \\
\text { (Aug, Jan); PFL (Aug) }\end{array}$ \\
\hline & Coleoptera & Bostrichidae^ ${ }^{\wedge}$ & Dinoderus & Dinoderus minutus & $F, A$ & 6.25 & CUHK (Jan) \\
\hline & & Buprestidae^ $\wedge$ & / & / & A & 6.25 & MK (Aug) \\
\hline & & Chrysomelidae^ & Bruchidius & Bruchidius terrenus & $G, F, A$ & 43.75 & CUHK (Jun) \\
\hline & & & Phyllotreta & Phyllotreta sp. & & & MK (Jan) \\
\hline & & & / & / & & & $\begin{array}{l}\text { CUHK (L. May, Jun); MK } \\
\text { (Aug) }\end{array}$ \\
\hline & & Curculionidae^ & l & / & $S L, F, U, A$ & 12.50 & CUHK (Aug) \\
\hline & & & Sitophilus & Sitophilus zeamais & & & MK (Jan) \\
\hline & & Nitidulidae^ & / & / & $\mathrm{F}$ & 18.75 & $\begin{array}{l}\text { CUHK (Aug); PFL (Aug, } \\
\text { Jan) }\end{array}$ \\
\hline & & / & / & / & & 12.50 & CUHK (Jun) \\
\hline & Diptera & Anthomyiidae^ & Delia & Delia platura & $S L, A$ & 2.33 & CUHK (Nov) \\
\hline & & Calliphoridae^ & Bengalia & Bengalia sp. & $S L, F$ & 4.65 & CUHK (Dec) \\
\hline & & & Chrysomya & $\begin{array}{l}\text { Chrysomya mega- } \\
\text { cephala }\end{array}$ & & & MW (Aug) \\
\hline & & Ceratopogonidae^ $^{\wedge}$ & / & / & $F, M$ & 2.33 & CUHK (Aug) \\
\hline & & Chironomidae & Tanytarsus & $\begin{array}{l}\text { Tanytarsus unagisepti- } \\
\text { mus }+\end{array}$ & FW & 6.98 & CUHK (E. May) \\
\hline & & & Chironomus & Chironomus sp. & & & MW (Jan), CUHK (Nov) \\
\hline & & Culicidae^ & Culex & Culex mimeticus & $F, F W, U$ & 46.51 & MW (Jan) \\
\hline & & & Culex & Culexvagans & & & $\begin{array}{l}\text { CUHK (Nov, Dec, Feb); } \\
\text { CLK (Jan); MK (Jan); } \\
\text { MW (Jan); PFL (Jan) }\end{array}$ \\
\hline & & & & Culexsp. & & & CUHK (Oct) \\
\hline & & & Lutzia & Lutzia sp. & & & CUHK (Oct) \\
\hline & & Drosophilidae & Drosophila & Drosophila immigrans & U & 9.30 & CUHK (Mar) \\
\hline & & & Scaptomyza+ & Scaptomyza pallida & & & CUHK (Mar); MK (Jan) \\
\hline & & & / & / & & & CUHK (Mar) \\
\hline & & Ephydridae & / & / & $\mathrm{G}, \mathrm{A}$ & 9.30 & CUHK (Sep) \\
\hline & & Muscidae^ & Dichaetomyia & Dichaetomyia bibax & $S L, G, F, U, A$ & 18.60 & $\begin{array}{l}\text { CUHK (Nov); CLK (Jan); } \\
\text { MW (Jan) }\end{array}$ \\
\hline & & & Lispe & Lispe pumila+ & & & CUHK (Sep) \\
\hline & & & & Lispe sp. & & & MW (Jan) \\
\hline & & & Passeromyia+ & $\begin{array}{l}\text { Passeromyia hetero- } \\
\text { chaeta+ }\end{array}$ & & & CUHK (Aug) \\
\hline & & & / & / & & & CUHK (Nov) \\
\hline & & Mycetophilidae & / & / & $S L, F$ & 2.33 & CUHK (Mar) \\
\hline & & Stratiomyidae & Microchrysa & Microchrysa flaviventris & $\mathrm{F}$ & 2.33 & CUHK (Aug) \\
\hline & & Syrphidae & Phytomia & Phytomia sp. & $\mathrm{F}$ & 4.65 & CUHK (Sep) \\
\hline & & & / & / & & & MW (Aug) \\
\hline & & Tachinidae & / & / & $\mathrm{F}$ & 11.63 & $\begin{array}{l}\text { CUHK (L. May, Dec); MK } \\
\text { (Jan); MW (Aug) }\end{array}$ \\
\hline & & Tephritidae & / & / & $F, A$ & 4.65 & CUHK (Jun, Jan) \\
\hline & & / & / & / & & 2.33 & MW (Aug) \\
\hline
\end{tabular}


Table 2 (continued)

\begin{tabular}{|c|c|c|c|c|c|c|c|}
\hline Class & Order & Family & Genus & Species & Habitats & $\% F O$ & Location (Time) \\
\hline & \multirow[t]{13}{*}{ Hemiptera } & Alydidae & / & / & $G, F, A$ & 1.67 & CUHK (Aug) \\
\hline & & Aphididae^ & Rhopalosiphum & $\begin{array}{l}\text { Rhopalosiphum rufiab- } \\
\text { dominale }\end{array}$ & $G, F, A$ & 1.67 & CUHK (Nov) \\
\hline & & Cicadellidae^^ & / & / & $G, F, A$ & 6.67 & $\begin{array}{l}\text { CUHK (Oct, Dec); MW } \\
\quad \text { (Jan) }\end{array}$ \\
\hline & & Coreidae^$\wedge^{\wedge}$ & / & / & $G, F, A$ & 3.33 & MW (Aug) \\
\hline & & Cymidae & / & / & $G, F, A$ & 1.67 & CUHK (Feb) \\
\hline & & Delphacidae^^ & Nilaparvata & Nilaparvatalugens & $\mathrm{G}, \mathrm{A}$ & 16.67 & CUHK (Oct); MW (Aug) \\
\hline & & & Sogatella & Sogatella furcifera & & & $\begin{array}{l}\text { CUHK (L. May, Sep, Feb); } \\
\text { CLK (Aug); MK (Aug); } \\
\text { MW (Aug) }\end{array}$ \\
\hline & & Diaspididae^^ & I & / & $G, F, A$ & 3.33 & CUHK (Feb, Mar) \\
\hline & & $\begin{array}{l}\text { Fulgoromorpha } \\
\text { (infraorder) }\end{array}$ & / & / & $\mathrm{F}, \mathrm{A}$ & 3.33 & CUHK (Jun) \\
\hline & & Miridae^^ & Prolygus + & Prolygus bakeri+ & $G, F, A$ & 30.00 & CUHK (Dec); MW (Jan) \\
\hline & & & / & / & & & $\begin{array}{l}\text { CUHK (L. May, Aug, Nov, } \\
\text { Dec, Jan); CLK (Aug, } \\
\text { Jan); MW (Aug, Jan) }\end{array}$ \\
\hline & & Rhyparochromidae & / & / & $G, F, A$ & 46.67 & $\begin{array}{l}\text { CUHK (Nov, Dec, Jan, } \\
\text { Feb, Mar); CLK (Jan); } \\
\text { MW (Jan); MW (Jan) }\end{array}$ \\
\hline & & / & / & / & & 1.67 & CUHK (Aug) \\
\hline & \multirow[t]{19}{*}{ Hymenoptera } & Apidae & Apis & Apis cerana & $\mathrm{F}, \mathrm{A}$ & 7.35 & $\begin{array}{l}\text { CUHK (May, Jun, Oct); } \\
\text { MK (Jan) }\end{array}$ \\
\hline & & Braconidae & Apanteles & Apanteles sp. & $\mathrm{F}$ & 2.94 & CUHK (Sep) \\
\hline & & & / & / & & & CUHK (L. May) \\
\hline & & Chalcididae & / & / & $\mathrm{F}$ & 5.88 & $\begin{array}{l}\text { CUHK (Jun, Nov, Feb, } \\
\text { Mar) }\end{array}$ \\
\hline & & Eulophidae & / & / & $\mathrm{F}$ & 1.47 & CUHK (Jan) \\
\hline & & Formicidae $\wedge$ & Camponotus & Camponotus sp. & $S L, G, F, U, A$ & 83.82 & CUHK (May) \\
\hline & & & Crematogaster & $\begin{array}{l}\text { Crematogaster rogen- } \\
\text { hoferi }\end{array}$ & & & $\begin{array}{l}\text { CUHK (E. May, L. May, } \\
\text { Jan); CLK (Jan); PFL } \\
\text { (Aug) }\end{array}$ \\
\hline & & & & Crematogaster sp. & & & CUHK (E. May) \\
\hline & & & Hypoponera & $\begin{array}{l}\text { Hypoponera opacic- } \\
\text { eps }+\end{array}$ & & & CUHK (May, Sep) \\
\hline & & & Pheidole & Pheidole sp. & & & $\begin{array}{l}\text { MK (Aug); CLK (Aug); } \\
\text { MW (Aug); PFL (Aug) }\end{array}$ \\
\hline & & & Solenopsis & Solenopsis geminata & & & CUHK (Oct); MK (Aug) \\
\hline & & & & Solenopsis invicta & & & $\begin{array}{l}\text { CUHK (Aug, Sep); CLK } \\
\text { (Aug); MK (Aug) }\end{array}$ \\
\hline & & & & Solenopsis sp. & & & $\begin{array}{l}\text { CUHK (Jun, Aug), MK } \\
\text { (Aug) }\end{array}$ \\
\hline & & & Technomyrmex & Technomyrmex sp. & & & CUHK (Jun) \\
\hline & & & Tetramorium & Tetramorium sp. & & & CUHK (Jun), MW (Aug) \\
\hline & & & / & / & & & $\begin{array}{l}\text { CUHK (E. May, L. May, } \\
\text { Jun, Oct, Nov); CLK } \\
\text { (Aug); MK (Aug); MW } \\
\text { (Aug); PFL (Aug) }\end{array}$ \\
\hline & & Ichneumonidae & Echthromorpha & Echthromorpha sp. & $\mathrm{F}$ & 5.88 & CUHK (Oct); CLK (Jan) \\
\hline & & & / & / & & & CUHK (Jun); CUHK (Nov) \\
\hline & & Platygastridae & / & / & & 1.47 & CUHK (Jun) \\
\hline & \multirow[t]{2}{*}{ Lepidoptera } & Geometridae & Bosara & Bosara sp. & $S L, F, U, A$ & 28.57 & PFL (Aug) \\
\hline & & & Chloroclystis & $\begin{array}{l}\text { Chloroclystis insigil- } \\
\text { lata+ }\end{array}$ & & & PFL (Aug) \\
\hline
\end{tabular}


Table 2 (continued)

\begin{tabular}{|c|c|c|c|c|c|c|c|}
\hline Class & Order & Family & Genus & Species & Habitats & $\% F O$ & Location (Time) \\
\hline & & Noctuidae^^ & Sesamia & Sesamia inferens & $S L, A$ & 14.29 & PFL (Aug) \\
\hline & & Pterophoridae & Stenoptilodes & $\begin{array}{r}\text { Stenoptilodes } \\
\text { taprobanes }\end{array}$ & $A$ & 28.57 & CUHK (Oct) \\
\hline & & & / & / & & & CUHK (Sep) \\
\hline & & Riodinidae & Abisara & Abisara sp. & & 14.29 & CUHK (Nov) \\
\hline & & Tortricidae^^$\wedge^{\wedge}$ & / & / & $\mathrm{F}, \mathrm{A}$ & 14.29 & CUHK (Oct) \\
\hline & Odonata & Libellulidae & Pantala & Pantala flavescens & FW & 100.00 & MK (Aug) \\
\hline
\end{tabular}

The \%FO column shows the percentage contribution of a family to its order. The Location (Time) column shows the location and time a prey item was found in this study. Families that are marked with $\wedge$ consist members of economically important pests and vectors of insect-borne diseases. Genus and/or species with + are not recorded in Hong Kong before according to Lau (2019). The habitats of different insect families followed Hill et al. (1982), which SL =Soil and Litter, G = Grassland, $\mathrm{F}=$ Forest, $\mathrm{FW}=$ Freshwater, $\mathrm{U}=$ Urban, $\mathrm{A}=$ Agriculture and $\mathrm{M}=$ Mangrove. ${ }^{1}$ Family Proctophyllodidae is an ectoparasitic family of feather mites and thus, this group was not treated as a prey item

curves showed a more flattened pattern (Additional file 2: Figure S1).

\section{Overview of the prey groups}

Insects were found to be the major food source for House Swifts. All but one sample and over $98 \%$ of the clones were found to consist of insect prey items. All prey samples were divided into nine groups based on their corresponding classes or orders (Arachnida, Blattodea, Coleoptera, Collembola, Diptera, Hemiptera, Hymenoptera, Lepidoptera, and Odonata). Among the nine prey groups identified, Hymenoptera, Hemiptera, and Diptera were found to be the most common prey for House Swifts in this study, with \%FO values of $42 \%, 37 \%$, and $26 \%$, respectively and together, they contributed to $80 \%$ of all clones, with $\% \mathrm{C}$ values of $30 \%, 27 \%$, and $23 \%$, respectively (Fig. 2).
As shown in Table 2, within the Hymenoptera group, bees (Apidae), wasps (Braconidae, Chalcididae, Eulophidae, Ichneumonidae, and Platygastridae), and ants (Formicidae) were found in the food spectrum of House Swifts, with ants occurring at the highest frequency (\%FO: 84\%). Ants were also found in the diets of swifts from all five colonies. The invasive Red Imported Fire Ants (Solenopsis invicta) and the tree nest-building Crematogaster rogenhoferi were detected in faecal samples from three different study sites.

In the Hemiptera group, aphids (Aphididae), leafhoppers (Cicadellidae), planthoppers (Delphacidae), plant bugs (Miridae), and seed bugs (Rhyparochromidae) were detected. Of these, seed bugs (\%FO: 46.67\%) and plant bugs (\%FO: 30\%) occurred most frequently (Table 2).

The seed bug family, Rhyparochromidae, was found in samples from all sites except PFL in January 2020. a

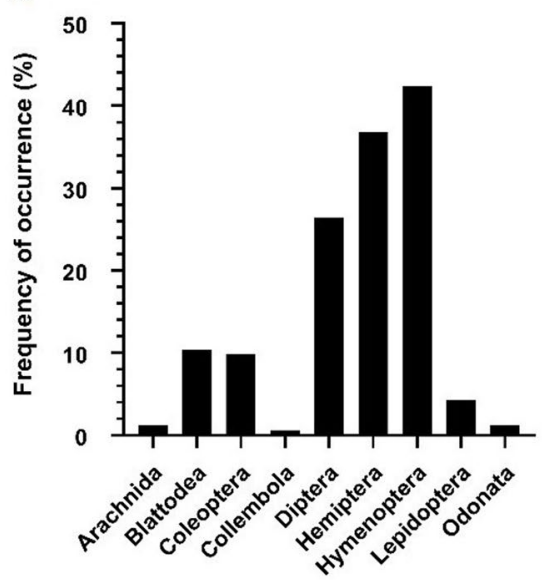

b

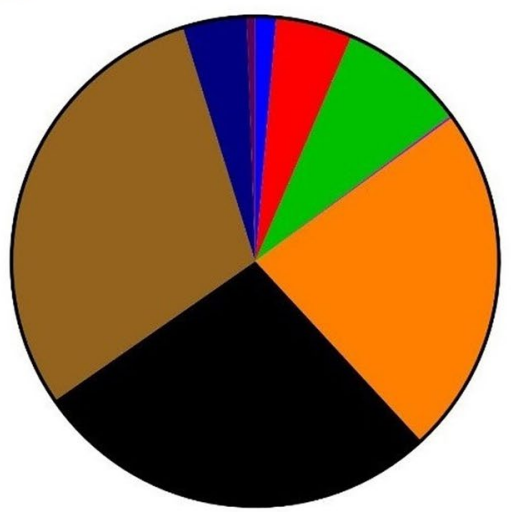

$1.38 \%$ Arachnida

$\square 5.08 \%$ Blattodea

$\square 8.39 \%$ Coleoptera

$\square 0.16 \%$ Collembola

$\square 23.09 \%$ Diptera

27.25\% Hemiptera

$\square 29.84 \%$ Hymenoptera

- $4.25 \%$ Lepidoptera

$\square 0.55 \%$ Odonata

Fig. 2 Graphical summary of the nine prey groups identified from 163 faecal samples of House Swifts containing identifiable prey DNA, collected from five different nest sites in Hong Kong between 2019 and 2020. a the frequency of occurrence (\%FO) of different prey groups in all 163 faecal samples; $\mathbf{b}$ the normalised percentage of clones (\%C) of different prey groups in all 163 faecal samples 
However, it was not possible to resolve this prey group to the genus or species level. The White-backed Planthopper (Sogatella furcifera) a notorious crop pest, was found at all sites except PFL, but planthoppers were found at a low frequency in the House Swift diet (Table 2).

In the Diptera group, 12 families of flies, as well as mosquitos (Culicidae), were identified. Mosquitos were the most prevalent members of this group (\%FO: 46.51), followed by house flies (Muscidae, \%FO: 18.6\%) and tachinid flies (Tachinidae, \%FO: 11.63\%). A Culex mosquito, Culex vagans, was the only species from this group detected in all five colonies (Table 2).

The Coleoptera group was found to be a relatively minor group of prey in this study. Of the samples in which Coleopterans were detected, $43.75 \%$ were found to have leaf beetles (Chrysomelidae). Auger beetles (Bostrichidae), jewel beetles (Buprestidae), true weevils (Curculionidae), and sap beetles (Nitidulidae) were also found in the diets of House Swifts (Table 2).

For the other minor insect prey groups, only a single species of termite, Odontotermes formosanus, was found within the Blattodea group, but this was a widespread prey item for House Swifts and was detected in more than four colonies. Four moth families (Geometridae, Noctuidae, Pterophoridae, and Tortricidae) and a single butterfly family (Riodinidae) were found in the Lepidoptera group. The Globe Skimmer (Pantala flavescens) was the only member in the Odonata group, with only a single record from the MK colony in August 2019 (Table 2).

In the Arachnida group, only mites were detected (Mesostigmata and Trombidiformes). Proctophyllodidae, a family comprising mostly feather mites, was also identified in extracted faecal DNA samples, but was probably not a prey item for the swifts. Finally, Seira sp., a springtail in the order Entomobryomorpha, was also detected in a faecal sample collected in March 2020 (Table 2).

\section{Temporal and spatial comparison of dietary composition}

The faecal samples collected at CUHK suggested that Hymenopteran prey were common and predominant in the diet of House Swifts during the breeding season (early May to September), having the highest frequency of occurrence and percentage of clones among all prey groups from early May to August (Fig. 3). This was especially true in the early May sampling, in which Crematogaster ants were identified in all faecal samples collected. The dominance of the Hymenoptera group diminished towards the end of the breeding season, and Hemiptera gradually replaced Hymenoptera as the predominant group of prey, in terms of both the frequency of occurrence and the percentage of clones, during the non-breeding season (October to March). The seed bug, Rhyparochromidae, was found at a relatively high frequency and proportion in February and March, and all samples collected in these two months comprised prey items from the Hemiptera group.

Besides these two major prey groups, the Dipteran group was also common, with occurrences in every sampling performed at the CUHK colony. However, it was not the predominant prey group in most months, except September and November, during the non-breeding season. Dipteran prey was found to have higher \%FO and $\% \mathrm{C}$ when compared to the non-breeding season, but the changes were relatively small when compared to Hymenoptera and Hemiptera (\%FO: $20 \%$ to $29 \%$; $\%$ C: $15 \%$ to 17\%; Fig. 3).

Multivariate analyses using NMDS for visualisation and ANOSIM for significance testing, based on permutations, revealed differences in dietary composition between the breeding and non-breeding seasons at the CUHK colony, for both dietary metrics (\%FO: $R=0.5307$, $p<0.01 ; \% \mathrm{C}: R=0.4773, p<0.01$; Fig. 4). Hemiptera (\%FO: 36\%; \%C: 38\%) and Hymenoptera (\%FO: 26\%; \%C: $28 \%)$ together had the greatest contribution, with more than $60 \%$ dissimilarity between the breeding and nonbreeding seasons for both dietary metrics. The Diptera group had the next greatest contribution (\%FO: $12 \%$; \% : 11\%; Fig. 5).

Multivariate analyses were also performed on all faecal samples collected from the five study sites. Significant differences in dietary composition between seasons were also found for both metrics (\%FO: $R=0.3753, p<0.01$; \%C: $R=0.3492, p<0.01$; Fig. 4). Hemiptera (\%FO: $25 \%$; \%C: $26 \%$ ) and Hymenoptera (\%FO: 26\%; \%C: 28\%) again had the greatest contribution to this dissimilarity, with a total contribution of approximately $50 \%$. The decrease in total contribution of these two groups was because Diptera contributed more (\%FO: $22 \%$; $\%$ C: $21 \%$ ) when data from other sites were included (Fig. 5). Increases in the $\% \mathrm{FO}$ and \%C values of the Dipteran prey group, from all study sites except CUHK, were observed in samples collected in January compared to those collected in August (Fig. 3).

The dietary composition of House Swifts from the five different nest sites in Hong Kong was found to be similar in August 2019 and January 2020 using multivariate analyses (\%FO: $R=0.03 p=0.4217$; \%C: $R=0.06, p=0.3833$ ). Pairwise comparisons between each of the five sites also showed no significant differences in dietary composition (Fig. 3).

\section{Discussion}

\section{Summary of the diet profiles}

In this study, the dietary composition of House Swifts in Hong Kong was analysed using DNA barcoding to identify prey items in faecal samples. Hymenoptera, 
Hemiptera, Diptera, Blattodea, and Coleoptera were identified as the major prey groups of House Swifts in this study. The major prey groups identified in faecal samples were similar to those identified in stomach contents in previous studies of the House Swift diet (Kow 1980; Nguyên Quang et al. 2006). Cucco et al. (1993) reported that Hymenoptera, Hemiptera, Diptera, and Coleoptera were the four most common groups of prey for aerial-feeding birds and there was no exception found in this study. Moths, butterflies, and dragonflies have also been found as prey items for House Swifts. Kow (1980) and Nguyên Quang et al. (2006) also identified Lepidoptera and Odonata as prey items in their dietary studies, but, similar to the findings presented here, they were found to be relatively minor prey items.

Hymenopterans were found to be predominant in the diet of House Swifts during the breeding season, and ants (Formicidae) were the most prevalent members of this group. The previous two studies of the House Swift diet also reported a greater prevalence of Hymenopteran prey, especially ants, during breeding seasons (Kow 1980; Nguyên Quang et al. 2006). Ant alates, which perform nuptial flights for reproduction, are found in dense aggregations in the air and the exploitation of swarming insects by swifts has been reported frequently (Lack and Owen 1955; Hespenheide 1975; Marín 1999).

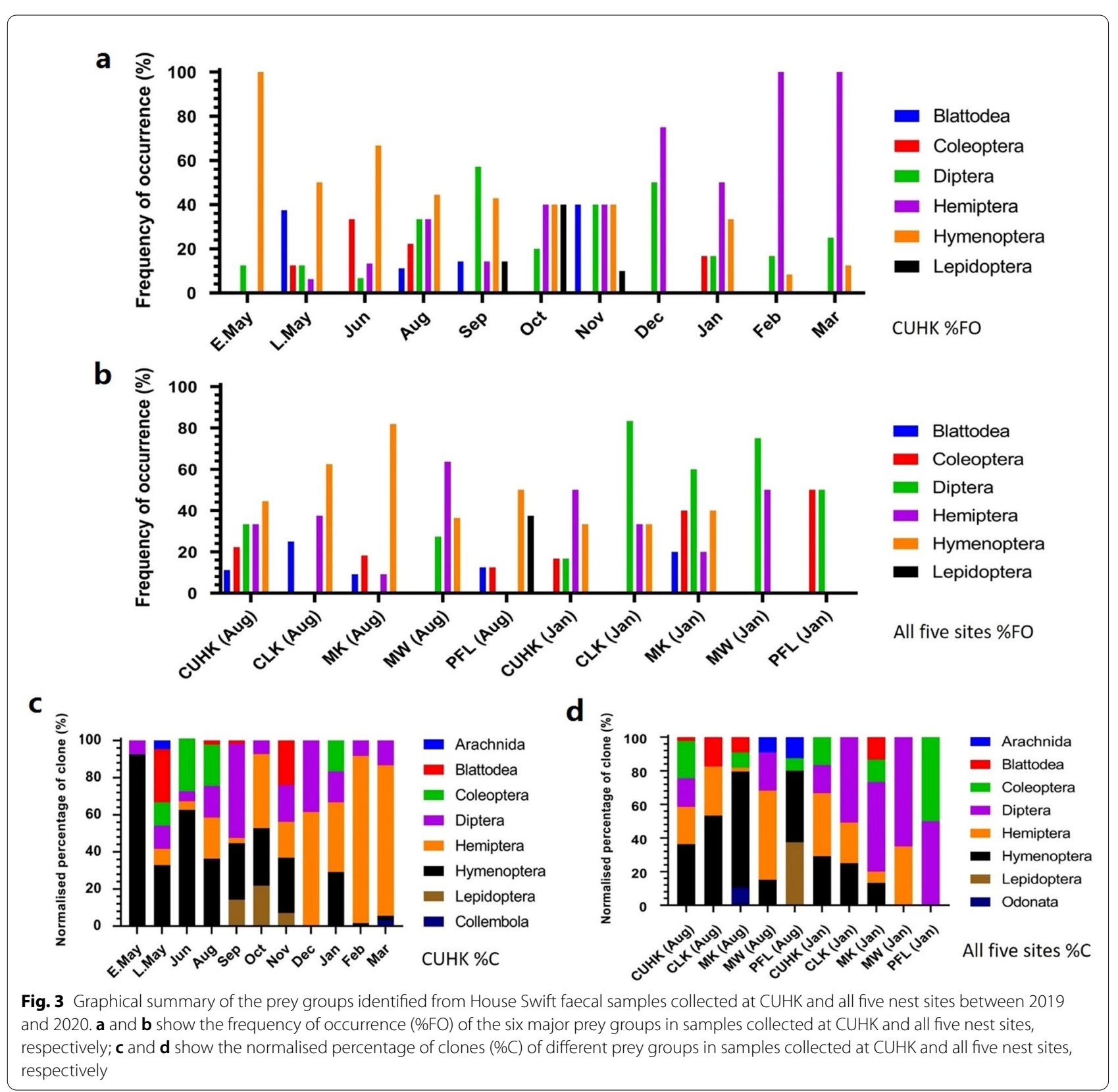




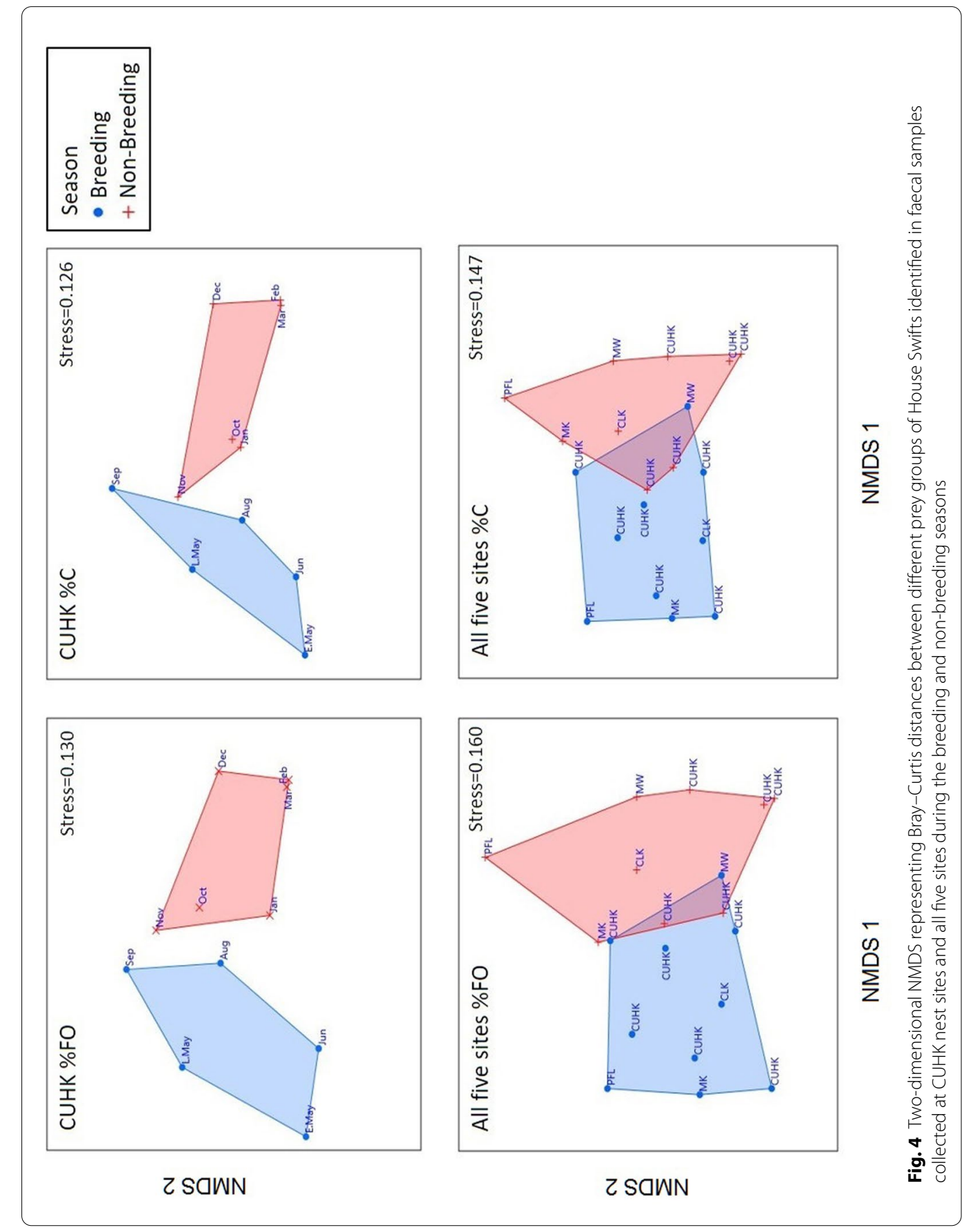



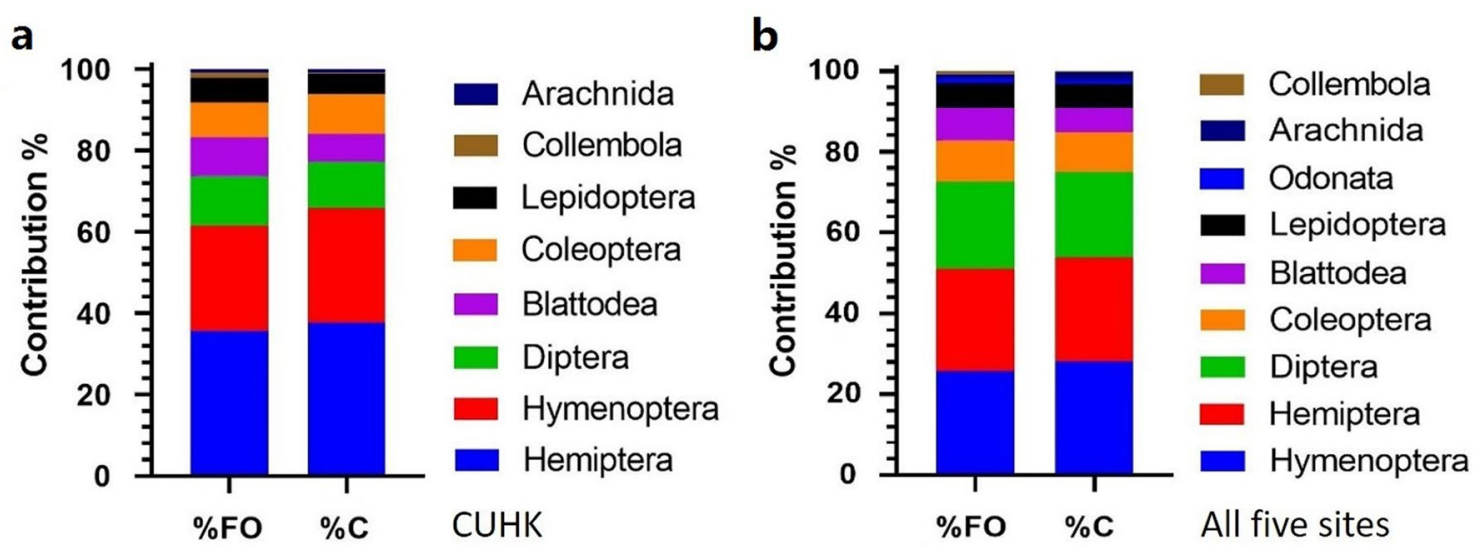

Fig. 5 Percentage contribution of different prey groups to the dissimilarities between the breeding and non-breeding seasons. a The percentage contribution of samples collected in CUHK only. $\mathbf{b}$ The percentage contribution of samples collected from all five nest sites

Hespenheide (1975) suggested that ants were relatively weak fliers when compared to more agile groups of insects, such as Dipterans, and thus, swifts may prefer preying on swarming ants rather than other aerial insects present in the air column. This may, in turn, reduce the capture effort and energy expenditure required by House Swifts. The reduction of capture effort is an important factor contributing to reproductive success, according to the optimal foraging theory (MacArthur and Pianka 1966). However, further research is necessary to determine the preferential foraging behaviour of House Swifts, as there are no data currently available regarding the presence and relative abundance of different kinds of aeroplankton species in Hong Kong.

In addition, some of the genera and/or species found in this study did not have previously known record in Hong Kong when compared to local insect checklist (Lau 2019; Table 2). For instance, Passeromyia, an underrepresented fly genus, with larvae known to be parasitic to bird nestlings (Grzywacz et al. 2014), was identified in the diet of House Swift. However, serious prudence should be taken when interpreting the unrecorded species, especially without morphological supports.

\section{Presence of insect pests in the diet}

Coleopteran prey items were found at a greater proportion in the diets of House Swifts in previous studies when compared to their dietary proportion in this study. Kow (1980) found that over $40 \%$ of the total stomach content was made up of Coleopteran prey, with a frequency of occurrence greater than $80 \%$. Coleoptera comprised $17 \%$ of the total prey content, with a frequency of occurrence greater than $60 \%$ in the study performed by Nguyên Quang et al. (2006).
In fact, $70 \%$ of the Coleopteran prey found in Kow's study were notorious grain pests, including the Cadelle Beetle (Tenebroides mauritanicus), Red Flour Beetle (Tribolium castaneum), and Lesser Grain Borer (Rhyzopertha dominica). The Rice Weevil (Sitophilus oryzae) contributed a further 7\% within this prey group (Kow 1980). The exploitation of cereal farmlands by Coleopteran pests may be the reason for the large proportion of prey items found to be Coleopteran pests in the study in Yunnan. In Hong Kong, agricultural activities are restricted to a small scale and most agricultural land is used to grow gardening crops and vegetables to satisfy local demand (Agriculture, Fisheries and Conservation Department HKSAR 2019). Therefore, grain-associated Coleopteran pests are not likely to be as abundant in Hong Kong, as they are in other localities with more extensive cereal farming.

Kow (1980) found that greater than $80 \%$ of the prey items identified in the stomachs of House Swifts could be categorised as economically important or diseasespreading pests. Similarly, a high proportion of pests were found in the diet of House Swifts in Hong Kong, with 20 out of the 44 identified families consisting of members that are economically important pests or vectors of insect-borne diseases (Table 2). These pests were found to have $\% \mathrm{C}$ and $\% \mathrm{FO}$ values of $65 \%$ for all samples. Kow (1980) estimated that each House Swift can consume more than $1 \mathrm{~kg}$ of aerial insects each year, which indicates a possible role of House Swifts in reducing the number of local pests.

For instance, the Striped Flea Beetle, Phyllotreta striolata, a common agricultural pest that consumes cruciferous crops, like Chinese flowering cabbage in local farmland (Agriculture, Fisheries and Conservation Department HKSAR 2005), was identified in the diet at 
a significant proportion within the Coleopteran group. The Brown Planthopper (Nilaparvata lugens) and Whitebacked Planthopper (Sogatella furcifera), which are infamous rice pests that cause major paddy rice yield losses each year in East and Southeast Asian countries (Hu et al. 2017), were also identified in the diet, along with other agricultural pests, including the Rice Root Aphid (Rhopalosiphum rufiabdominale), Stem Borer (Sesamia inferens), and Maize Weevil (Sitophilus zeamais).

Haematophagic mosquitoes (Culicidae) were also a component of the House Swift diet and Culex spp. were found to make up a large proportion of the diet in winter. Some of the local Culex spp. are known to transmit Japanese encephalitis to humans (Zhao et al. 2018), but the species identified in the House Swift diet have not yet been confirmed as zoonotic vectors. It is worth mentioning that House Swifts almost exclusively prey on a single species of mosquitoes, Culex vagans, and this species was found in samples from all the study sites. The reason for the prevalence and widespread preference of a single species is unknown, but Culex spp. are known to feed on the blood of avian hosts and Culex pipiens has been shown to preferentially select a specific avian host (Simpson et al. 2009). Thus, a possible scenario is that Culex vagans preferentially fed on swifts, while also being consumed by the swifts. Further investigation is required to confirm such a complex parasite-host interaction.

The diet also consisted of the Red Imported Fire Ant (Solenopsis Invicta), which is a notorious invasive species first discovered in Hong Kong in late 2004. These ants cause damage to economically important crops worldwide and their stings can cause fiery sensations or even induce strong immune responses (Wong and Yuen 2005). The presence of the Red Imported Fire Ant in the diet of local House Swifts implies that nuptial flights may be the route used for their rapid spread and colonisation in Hong Kong.

\section{Seasonal and site differences in diet profiles}

Seasonal differences in dietary composition were found in this study, with Hymenoptera being most prevalent in the breeding season, but Diptera and Hemiptera showing the greatest prevalence in the non-breeding season. The seasonality shown in this study was similar to the results of a forest invertebrate seasonal study performed by Kwok and Corlett (2002) in Hong Kong, in which Malaise traps were used to capture flying insects in the understory of the Tai Po Kau Nature Reserve, a secondary forest near the CUHK nest sites used in this study. They found a high abundance of Hymenoptera in summer and a low abundance in winter, coinciding the changes in the abundance of Hymenopteran preys between breeding and non-breeding season of the House Swifts in this study.

Further, they found that Diptera was the most frequently captured insect group. However, these insects did not follow a seasonal pattern and were found at high abundance and biomass levels, even in winter when all other groups of insects captured showed relatively low biomass levels. This observation was also in line with the higher prevalence of Dipteran prey items observed in the diet during the non-breeding season in this study when the availability of Hymenopteran preys was low. Hemiptera species were also found to be the predominant prey items for house swifts during the non-breeding season, especially for the CUHK colony. However, the Malaise trap study lacked data on Hemiptera and Homoptera abundance in any season and thus, a comparison cannot be made for these groups.

It is clear that the presence of aerial arthropods shapes the diet of any opportunistic aerial feeder. Hence, seasonal variation in the composition of the local arthropod community contributes to the changes in the dietary composition of House Swifts between seasons.

This study also found no significant differences in dietary composition between different colonial sites within Hong Kong. Chan et al. (2019) showed that landscapes within the home range of swiftlets affected the composition of the diet. Although no tracking study has been performed for House Swifts, the average home range of the edible-nest swiftlets, Aerodramus fuciphagus, has been shown to be approximately $64 \mathrm{~km}^{2}$, with a flying distance ranging from 2 to $6 \mathrm{~km}$ (Burhanuddin and Noor 2017).

If House Swifts have similar home range, swifts from the five studied sites would cover similar mixed landscapes, comprising of urban and suburban areas, in which most of the nest sites were situated; as well as Country Parks, which are mostly secondary woodlands or shrublands (Delang and Hang 2009). Thus, the similar landscapes within the home ranges of the different nest sites may explain the similar dietary compositions found at the different sites in this study.

\section{Efficacy of molecular profiling of bird diet}

Of all taxa recovered in this study, $60 \%$ and $40 \%$ could be identified to the species and genus level, respectively. However, compared to dietary studies of insectivorous bats using faecal samples for DNA barcoding, the identification rate was relatively low. For example, in a study of the diets of multiple bat species in England, $72 \%$ of the sequences showed over $99.3 \%$ similarity with reference sequences deposited in the BOLD system and the majority were identified to the species level (Zeale et al. 2011). In a study of Little Brown Bats (Myotis lucifugus) in Canada, the majority of sequences were identified to 
the genus or species level after comparisons to reference sequences in the BOLD system (Clare et al. 2011).

The absence of reference barcodes in the database that match the query sequences is the main factor that hinders species-level identification. Less effort has been put into the deposition of insect barcodes in the reference database in Asian countries, which may explain the relatively low identification rate in this study compared to studies conducted in Europe and North America. A recent study of swiftlet diets using DNA barcoding, conducted in Malaysia, also had difficulties in successful identification up to low-ranked taxa. Out of 266 operational taxonomic units with prey sequences identified from swiftlet faecal samples, only three were successfully identified to the species level (Chan et al. 2019). Despite the identification to precise taxa being one of the major advantages of DNA barcoding over conventional dietary analysis methods, incomplete barcode databases greatly limit the potential of DNA barcoding for precise dietary analysis. Thus, joint efforts between Asian countries in the deposition of local or regional arthropod barcodes into the barcode database would be beneficial for future studies.

Moreover, despite the fact that many dietary studies based on DNA barcoding have attempted to use clone proportion or relative read abundance as estimations of the actual proportion of prey intake by the predator, these methods are controversial, as mismatches between the universal primers and the template can cause major bias in the proportioning of prey DNA, making quantitative data less reliable. This problem has been demonstrated in mock testing (Piñol et al. 2015).

Clone proportion was calculated in this study, but this metric should not be interpreted as the actual abundance in House Swifts' prey, but rather treated as auxiliary to the frequency of occurrence. Qualitative dietary metrics are more reliable indicators of the actual dietary composition of House Swifts in this study, but they have the risk of overrepresenting rare prey items that have low abundance in each sample, but are prevalent in a set of samples (Deagle et al. 2019). However, since the \%C and $\%$ FO values were similar, \%FO may be a reliable indicator of the contribution of different prey groups in this study.

The non-asymptotic taxon accumulation curves also suggested that prey taxon discovered in this study might under-represent the actual diet of the House Swift in Hong Kong. Environmental degradation of DNA in faecal samples is one of the major obstacles in recovering prey. It has been demonstrated that exposing samples to sunlight and rain can greatly prey DNA amplification (Oehm et al. 2011).

\section{Conservation implications}

Although Hong Kong is a densely populated metropolis, around $40 \%$ of the lands has been designated as Countries Parks. These large areas of legally protected secondary forests, shrublands and grassland, as well as patches of agricultural farmland, can be found contiguous with the urban areas. Local House Swifts may utilize diverse landscapes as their foraging grounds, because many of the prey items found in this study most likely originated from forested, grassed or agricultural areas (Table 2). Hence, urbanisation of the forested areas is a potential threat to the local population of House Swifts. Conserving the urban green spaces and rural countryside is vital for maintaining local biodiversity and ecological balance.

Moreover, similar to a recent study of the diet of swiftlets (Chan et al. 2019) and other DNA barcoding-based studies of the diet of various bird species, such as albatrosses (McInnes et al. 2017), penguins (Deagle et al. 2007), and sandpipers (Gerwing et al. 2016), this study further confirmed the utility of DNA barcoding as a noninvasive method for ecologists to understand the diet of birds. A thorough understanding of a species' diet is crucial for its conservation, especially for endangered species, as it has implications for resource management or captive breeding programmes aimed at saving these species. Hence, in the near future, increasing use of this technique is expected to aid the design of conservation strategies for endangered species.

\section{Conclusion}

In conclusion, this study investigated the diet of House Swifts in Hong Kong using DNA barcoding of faecal samples. This is the first such study performed in the territories of Hong Kong. Changes in the dietary composition of House Swifts between the breeding and non-breeding seasons were observed in this study. Results also suggest a possible role of House Swifts in reducing the number of pests. These data will facilitate the identification of potential threats to House Swifts in Hong Kong, where there is heavy urbanisation and rapid expansion of the city due to new town developments.

\section{Supplementary Information}

The online version contains supplementary material available at https://doi. org/10.1186/s40657-021-00242-z.

Additional file 1: Table S1. Raw data on amplification and cloning success of the 163 faecal samples of House Swifts collected between 2019 to 2020 .

Additional file 2: Figure S1. Taxon accumulation curves (red) of different prey taxa levels (a species; $\mathbf{b}$ families/infraorders; c orders) recovered from the 163 faecal samples of House Swifts collected between 2019 to 2020 with $95 \%$ confidence intervals (blue). 


\section{Acknowledgements}

We thank the Fire Services Department of the Hong Kong Government for kindly giving permission for work in the Mui Wo and Pok Fu Lam Fire Stations; we also gratefully thank the anonymous reviewers for their valuable suggestions.

\section{Authors' contributions}

CTC conceived and designed the experiments, collected the data, performed the analyses, prepared the figures and tables and wrote the paper; HSW collected and contributed data on swift nests; MLK and QM contributed materials and helped perform data analysis and KMC conceived and designed the experiments, obtained and allocated research funding (one-line budget, School of Life Sciences, CUHK), contributed reagents and materials, and reviewed the draft of the paper. All authors read and approved the final manuscript.

\section{Funding}

This study was supported by one-line budget (5501703), provide from the School of Life Sciences, The Chinese University of Hong Kong.

\section{Availability of data and materials}

The sequencing data deposited in the Dryad (https://doi.org/10.5061/dryad .mpg4f4qxd).

\section{Ethics approval and consent to participate}

Not applicable.

\section{Consent for publication}

Not applicable.

\section{Competing interests}

The authors declare that they have no competing interests.

\section{Author details}

${ }^{1}$ School of Life Sciences, The Chinese University of Hong Kong, Sha Tin 999077, N.T, China. ${ }^{2}$ Swift and Swallow Research Group, The Hong Kong Bird Watching Society, 7C, V Ga Building, 532 Castle Peak Road, Lai Chi Kok, Kowloon, Hong Kong 999077, China.

Received: 30 July 2020 Accepted: 7 January 2021

Published online: 03 February 2021

\section{References}

Agriculture, Fisheries and Conservation Department HKSAR. Integrated pest management for flea beetles. 2005 (In Chinese). https:/www.afcd.gov. hk/tc_chi/agriculture/agr_useful/agr_useful_com/agr_useful_com_flea/ agr_useful_com_flea.html. Accessed 14 May 2020.

Agriculture, Fisheries and Conservation Department HKSAR. Agriculture in HK. 2019. https://www.afcd.gov.hk/english/agriculture/agr_hk/agr_hk.html. Accessed 14 May 2020

BirdLife International. Apus nipalensis. The IUCN Red List of Threatened Species 2016. 2016. https://dx.doi.org/https://doi.org/10.2305/IUCN.UK.2016-3.RLTS. T22686861A93129265.en.

Burhanuddin M, Noor HM. Ranging behaviour of edible nest swiftlet (Aerodramus sp.) in Kuala Langat district, Selangor, Malaysia. Malays Appl Biol. 2017;46:59-66.

Carey GJ, Chalmers ML, Diskin DA, Kennerley PR, Leader PJ, Leven MR, et al. The avifauna of Hong Kong. Hong Kong, China: Hong Kong Bird Watching Society; 2001.

Chan KS, Tan J, Goh WL, Earl of Cranbrook. Diet profiling of house-farm swiftlets (Aves, Apodidae, Aerodramus sp.) in three landscapes in Perak, Malaysia, using high-throughput sequencing. Trop Ecol. 2019;60:379-88.

Chantler P, Driessens G. Swifts: a guide to the swifts and treeswifts of the world. Sussex, UK: Pica Press; 1995.

Cheng Z, Zhou B. Diet-analyses of the large white-rumped swift, Apus pacificus, at Chenlushan Island in the Yellow Sea and examination of their pattern of activities by radar. Acta Zool Sin. 1987;33:180-6 ((In Chinese)).
Clare EL, Barber BR, Sweeney BW, Hebert PDN, Fenton MB. Eating local: influences of habitat on the diet of little brown bats (Myotis lucifugus). Mol Ecol. 2011:20:1772-80.

Collins CT, Anderson MD, Johnson DN. Food of the Little Swift Apus affinis and African Black Swift Apus barbatus in South Africa. Ostrich. 2010;81:45-50.

Collins CT, Hespenheide HA. Diet of the Pygmy Palm-Swift (Tachornis furcata). Ornitol Neotrop. 2016;27:63-6.

Cucco M, Bryant DM, Malacarne G. Difference in diet of Common (Apus apus) and Pallid (A. pallidus) Swifts. Avocetta. 1993;17:131-8.

Cusimano CA, Massa B, Morganti M. Importance of meteorological variables for aeroplankton dispersal in an urban environment. Ital J Zool. 2016;83:263-9.

Deagle BE, Gales NJ, Evans K, Jarman SN, Robinson S, Trebilco R, et al. Studying seabird diet through genetic analysis of faeces: a case study on macaroni penguins (Eudyptes chrysolophus). PLoS ONE. 2007;2:e831.

Deagle BE, Thomas AC, MCInnes JC, Clarke LJ, Vesterinen EJ, Clare EL, et al. Counting with DNA in metabarcoding studies: how should we convert sequence reads to dietary data? Mol Ecol. 2019;28:391-406.

Delang CO, Hang YY. Remote sensing-based estimation of carbon sequestration in Hong Kong country parks from 1978 to 2004. Open Environ Sci. 2009:3:97-115.

Garcia-del-Rey E, Collins CT, Volpone NW. Food composition of the endemic Plain Swift Apus unicolor in the Canary Islands (Macaronesia). Ardea. 2010;98:211-5.

Gatehouse AG. Behavior and ecological genetics of wind-borne migration by insects. Annu Rev Entomol. 1997;42:475-502.

Gerwing TG, Kim J-H, Hamilton DJ, Barbeau MA, Addison JA. Diet reconstruction using next-generation sequencing increases the known ecosystem usage by a shorebird. Auk. 2016;133:168-77.

Grzywacz A, Khoobdel M, Akbarzadeh K. First palaearctic record of the bird parasite Passeromyia heterochaeta (Diptera: Muscidae) from the Iranian Persian Gulf islands. J Arthropod Borne Dis. 2014;8:224-7.

Hails CJ, Amirrudin A. Food samples and selectivity of White-bellied Swiftlets Collocalia esculenta. Ibis. 1981:123:328-33.

Hajibabaei M, Janzen DH, Burns JM, Hallwachs W, Hebert PDN. DNA barcodes distinguish species of tropical Lepidoptera. P Natl Acad Sci USA. 2006;103:968-71.

Hall TA. Bioedit: a user-friendly biological sequence alignment editor and analysis program for Windows 95/98/nt. Nucleic Acids Symp Ser. 1999;41:95-8.

Hammer $\varnothing$, Harper DAT, Ryan PD. PAST: paleontological statistics software package for education and data analysis. Palaeontol Electron. 2001;4:1-9.

Hespenheide HA. Selective predation by two swifts and a swallow in Central America. Ibis. 1975;117:82-99.

Hill DS, Hore P, Thornton IWB. Insects of Hong Kong. Hong Kong, China: Hong Kong University Press; 1982

Hu G, Lu MH, Tuan HA, Liu WC, Xie MC, McInerney CE, et al. Population dynamics of rice planthoppers, Nilaparvata lugens and Sogatella furcifera (Hemiptera, Delphacidae) in Central Vietnam and its effects on their spring migration to China. Bull Entomol Res. 2017:107:369-81.

Kopij G. Diet of swifts (Apodidae) and swallows (Hirundinidae) during the breeding season in South African grassland. Acta Ornithol. 2000;35:203-6.

Kow C. Food analysis of the house swift (Apus affinis subfurcatus). Zool Res. 1980;1:247-55 ((In Chinese)).

Kumar S, Stecher G, Li M, Knyaz C, Tamura K. MEGA X: molecular evolutionary genetics analysis across computing platforms. Mol Biol Evol. 2018;35:1547-9.

Kwok HK, Corlett RT. Seasonality of forest invertebrates in Hong Kong. South China J Trop Ecol. 2002;18:637-44.

Lack D, Owen DF. The food of the Swift. J Anim Ecol. 1955;24:120-36.

Lau CSK. Checklist of insects of Hong Kong. Hong Kong, China: Agricultire, Fisheries and Conservation Department; 2019.

Lourie SA, Tompkins DM. The diets of Malaysian swiftlets. Ibis. 2000;142:596-602.

MacArthur RH, Pianka ER. On optimal use of a patchy environment. Am Nat. 1966;100:603-9.

Marín M. Food, foraging, and timing of breeding of the Black Swift in California. Wilson Bull. 1999;111:30-7.

McInnes JC, Alderman R, Lea MA, Raymond B, Deagle BE, Phillips RA, et al. High occurrence of jellyfish predation by black-browed and Campbell albatross identified by DNA metabarcoding. Mol Ecol. 2017;26:4831-45.

Meiklejohn KA, Damaso N, Robertson JM. Assessment of BOLD and GenBank their accuracy and reliability for the identification of biological materials. PLOS ONE. 2019:14:e0217084. 
Nguyên Quang P, Voisin JF, Lâm NT. Biology of the House Swift Apus nipalensis (Hodgson) in Vietnam. Rev Écol (Terre Vie). 2006;61:383-95.

Oehm J, Juen A, Nagiller K, Neuhauser S, Traugott M. Molecular scatology: how to improve prey DNA detection success in avian faeces? Mol Ecol Resour. 2011;11:620-8.

Piñol J, Mir G, Gomez-Polo P, Agustí N. Universal and blocking primer mismatches limit the use of high-throughput DNA sequencing for the quantitative metabarcoding of arthropods. Mol Ecol Resour. 2015;15:819-30.

Ratnasingham S, Hebert PDN. BOLD: the Barcode of Life Data System (www. barcodinglife.org). Mol Ecol Notes. 2007;7:355-64.

Ross HA, Murugan S, Li WLS. Testing the reliability of genetic methods of species identification via simulation. Syst Biol. 2008;57:216-30.

Simpson JE, Folsom-O'Keefe CM, Childs JE, Simons LE, Andreadis TG, Diuk-Wasser MA. Avian host-selection by Culex pipiens in experimental trials. PLoS ONE. 2009:4:e7861.

Sousa LL, Silva SM, Xavier R. DNA metabarcoding in diet studies: unveiling ecological aspects in aquatic and terrestrial ecosystems. Environ DNA. 2019;1:199-214

Tarburton MK. The food of White-rumped Swiftlet (Aerodramus spodiopygius) in Fiji. Notornis. 1986;33:1-6.

Valentini A, Pompanon F, Taberlet P. DNA barcoding for ecologists. Trends Ecol Evol. 2009;24:110-7.
Vestheim $\mathrm{H}$, Jarman SN. Blocking primers to enhance PCR amplification of rare sequences in mixed samples - a case study on prey DNA in Antarctic krill stomachs. Front Zool. 2008;5:12.

Waugh DR. Predation strategies in aerial feeding birds. Doctoral Thesis. Stirling: University of Stirling; 1978.

Wilson JJ, Rougerie R, Schonfeld J, Janzen DH, Hallwachs W, Hajibabaei M, et al. When species matches are unavailable are DNA barcodes correctly assigned to higher taxa? An assessment using sphingid moths. BMC Ecol. 2011;11:18.

Wong SSY, Yuen KY. Red imported fire ants in Hong Kong. Hong Kong Med J. 2005;11:131-2.

Zeale MRK, Butlin RK, Barker GLA, Lees DC, Jones G. Taxon-specific PCR for DNA barcoding arthropod prey in bat faeces. Mol Ecol Resour. 2011;11:236-44.

Zhao S, Lou Y, Chiu APY, He D. Modelling the skip-and-resurgence of Japanese encephalitis epidemics in Hong Kong. JTheor Biol. 2018;454:1-10. 